
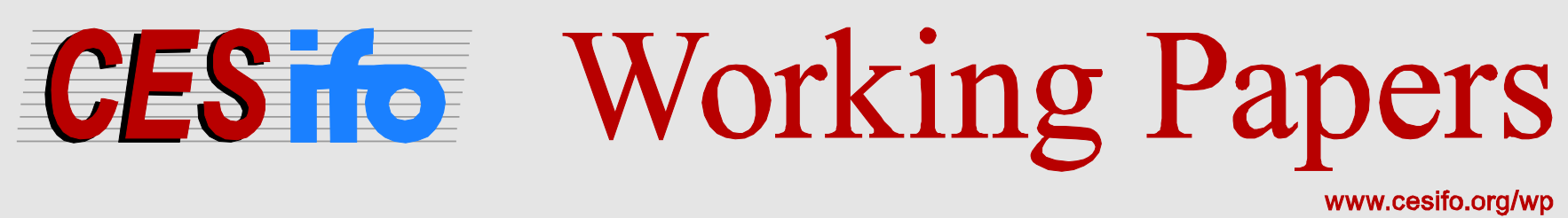

\title{
Donor Ideology and Types of Foreign Aid
}

\author{
Viktor Brech \\ Niklas Potrafke
}

CESIFO WORKING PAPER NO. 4314

CATEGORY 2: Public CHOICE

JUNE 2013
An electronic version of the paper may be downloaded
- from the SSRN website: Www.SSRN.com
- from the RePEc website: Www.RePEc.org
- from the CESifo website: www.CESifo-group.org/wp

\section{CESifo}




\title{
Donor Ideology and Types of Foreign Aid
}

\begin{abstract}
We examine how donor government ideology influences the composition of foreign aid flows. We use data for 23 OECD countries over the period 1960-2009 and distinguish between multilateral and bilateral aid, grants and loans, recipient characteristics such as income and political institutions, tied and untied aid, and aid by sector. The results show that leftist governments increased the growth of bilateral grant aid, and more specifically grant aid to least developed and lower middle-income countries. Our findings confirm partisan politics hypotheses because grants are closely analogous to domestic social welfare transfer payments, and poverty and inequality are of greatest concern for less developed recipient countries.
\end{abstract}

JEL-Code: F350, F360, F530, F590, D720, C230.

Keywords: foreign aid, government ideology, partisan politics, international organizations, panel data.

Viktor Brech

ICES

George Mason University

4400 University Drive

USA - Fairfax, VA, 22030

viktor.brech@gmail.com
Niklas Potrafke

Ifo Institute - Leibniz-Institute

for Economic Research

at the University of Munich

Department of Public Finance

Poschingerstraße 5

Germany - 81679 Munich

potrafke@ifo.de

This paper is forthcoming in the Journal of Comparative Economics. 


\section{Introduction}

Foreign aid provides a powerful test case for partisan hypotheses. Survey data and political rhetoric suggest that foreign aid policies are highly divisive ideologically. Total aid accounts for a small fraction of government budgets in donor countries, so that changes in overall budget constraints are less important for explaining the variation in aid flows, as compared to other policy areas. In addition, the welfare implications of foreign aid policy for voters are likely to be limited. Donor country governments may thus indulge their ideological preferences regarding foreign aid. ${ }^{3}$

Compared to its share of donor government budgets, foreign aid frequently accounts for a substantial fraction of government revenue in recipient countries. The ultimate impact of aid on welfare in recipient economies has nevertheless proven to be elusive. This disconnect has inspired many empirical studies on foreign aid, investigating the (dubious) effects of aid on economic growth (Doucouliagos and Paldam 2008, 2011, Collier and Hoeffler 2004, McGillivray et al. 2005, Ouattara and Strobl 2008) and on various development indicators (Chong et al. 2009, Dreher et al. 2008a, Bjørnskov 2010, Gupta et al. 2003), as well as the effects of political institutions on aid outcomes (Kilby and Dreher 2010, Boone 1996, Knack and Rahman 2007, Epstein and Gang 2009, Rioux and Van Belle 2005), and the implications of aid volatility on recipient economies (Buffie et al. 2009, Arellano et al. 2009).

Scholars examine the determinants of foreign aid. Early studies distinguished between "need"-driven foreign aid that is based on objective deprivation on the part of a recipient country and "interest"-based aid that is driven by donors' concerns with trade, security, or other matters of national interest (Maizels and Nissanke 1984, McKinlay and Little 1977, 1978). Other studies scrutinize the effect of particular recipient characteristics on aid flows (Alesina and Dollar 2000), or focus on donor characteristics that

\footnotetext{
${ }^{3}$ And more broadly, it pertains to the debate as to whether "parties matter". See, for example, Osterloh (2012) and Potrafke (2012).
} 
explain the variation in aid policies along various dimensions (Younas 2008, Fleck and Kilby 2001, 2010, Tsoutsoplides 1991, Wang and Jin 2013). Some empirical studies investigate aid determinants at the level of donor-recipient pairs, taking recipient, donor, and their pair-specific characteristics into account (Berthélemy 2004, 2006).

Related work by political scientists includes comparative case studies (Schraeder et al. 1998; Thérien and Noël 2000 summarize this literature) and empirical studies (Noël and Thérien 1995, Thérien and Noël 2000). Government ideology is one possible explanation of donor behavior (Imbeau 1988, Meernik et al. 1998). ${ }^{4}$ Tingley's $(2010 a, b)$ is the first panel data study to examine the effect of donor ideology using the full range of available administrative data. He finds that leftwing governments increased aid to lower income countries, but not to middle income countries. Round and Odedokun (2004) and Lundsgaarde et al. (2007) find no such effects. By using Extreme Bounds Analysis (EBA), Fuchs et al. (2012) show that government ideology in donor countries did not influence overall, multilateral and bilateral aid. In Germany, leftwing governments committed even less aid than rightwing governments (Dreher et al. 2013). ${ }^{5}$

We investigate whether donor government ideology influences the composition of foreign aid flows. We distinguish between concessionary loans and pure grant aid; between aid to subsets of recipients by income group and political institutions; between unconditional aid and aid that has been "tied" to the purchase of export goods from the donor; and aid allocations to specific sectors.

\footnotetext{
${ }^{4}$ Noël and Thérien suggest that more fundamental differences in the kind of welfare state that developed in different donor countries account for major differences in aid policies across countries. Thérien and Noël (2000) also suggest that the year-on-year variation in the composition of governing coalitions does not fully capture the long-term institutional differences that determine aid policies.

${ }^{5}$ Scholars also investigate political determinants other than ideological orientation of donor governments (Dreher et al. 2008b, Kuziemko and Werker 2006, Boschini and Olofsgard 2002, Mascarenhas and Sandler 2006).
} 


\section{Hypotheses and related literature}

Our basic prediction is that leftwing governments commit and disburse more foreign aid than rightwing governments. This hypothesis is based on the analogy between foreign aid and domestic social welfare spending. Committing public resources to alleviate poverty and to reduce socioeconomic inequality is a central tenet of what is associated with "left" politics. Foreign aid should be more strongly favored by leftwing governments to the extent that it serves these purposes. In terms of the conventional dichotomy of "donor interests vs. recipient needs", we would expect a partisan effect on aid if the needs of recipient populations are at least partly determining aid policies.

At the level of rhetoric and general ideological beliefs, the link between foreign aid and the political left is well established. Noël and Thérien (2008) summarize the support for foreign aid on the political left: "Motivated by an ethics that looked upon the inequitable sharing of wealth as a barrier to human dignity, progressives considered that the values of solidarity and democracy upheld in the developed world had to be projected on a world scale ... [T] $[$ he welfare state had to be extended across borders in order to bring about a 'welfare world'"' (Noël and Thérien 2008, p. 132). Noël and Thérien (1995) also cite Blair (1969), who writes that "[the] rationale for attacking poverty is much the same at home and abroad though better recognized domestically" (p. 683), and Lumsdaine (1993), who concludes that welfare state policies and foreign aid ultimately express the same set of values (p. 121).

Empirical studies using survey data show that supporters of opposing political parties in donor countries are often sharply divided in their preferences over policy options towards developing countries. Chong and Gradstein (2008) and Paxton and Knack (2012) use data from the World Values Survey and find that individuals' self-reported location on the ideological (left-right) spectrum correlates with their answer to the questions "Do you think that this country should provide more or less economic aid to poorer countries?" ("Do you think that the wealthier nations should give more financial help to the poorer 
nations or are they giving enough now?"). ${ }^{6}$ Potrafke and Ursprung (2013) find a similar ideological divide among the population of university students in Germany. By using new US public opinion survey data, Milner and Tingley (2013) find that conservative voters oppose and liberal voters support aid through multilateral institutions.

The voting behavior of political representatives provides another source of evidence. While individual attitudes and political rhetoric are suggestive, changes in governing coalitions need not result in policy changes that directly reflect either stated preferences of particular constituencies, or even of politicians. Talk is cheap, and may simply serve self-signaling purposes (e.g., Potrafke and Ursprung 2013). It is therefore significant that data on the voting patterns of parliamentarians on matters of foreign aid document the plausibility of the partisan hypothesis (i.e. the notion that party ideology affects foreign aid giving). Milner and Tingley (2010 and 2011) show that members of the US Congress are more likely to vote in favor of foreign aid if they are located on the political left, whereas those on the political right will be more likely to vote against it, and to support substitution of trade for aid (see also Fleck and Kilby 2006). The ideological divide over aid is shown to be greater than that over trade issues, suggesting that foreign aid flows provide a particularly strong test for partisan effects in public spending.

We hypothesize that leftwing governments will give more aid, which we measure by ideology indices that weigh the government and the underlying ideological beliefs. We also expect a stronger partisan effect for types of aid flows that are most closely analogous to domestic social welfare transfer payments. We discuss our more detailed predictions in the following sections.

\section{Loans vs. Grants}

Overall gross ODA (Official Development Assistance) encompasses grants and concessionary loans. Grant aid is distinguished by the fact that it carries no repayment obligation, i.e. it is a pure transfer

\footnotetext{
${ }^{6}$ Other good predictors are self-reported confidence in the government and satisfaction with people in office.
} 
payment. Principal amount and accrued interest payments on a loan, on the other hand, need to be repaid. In order to count as ODA as defined in the OECD accounting framework, however, loans must be extended on favorable terms that amount to a "grant equivalent" (i.e. the difference between principal and the present discounted value of repayment obligations) of at least $25 \%$.

The overall share of loans in total ODA has dropped significantly since the 1970s. Figure 1 shows the share of loans in total ODA that OECD countries have designated on average in each year (including all donor countries for which data is available for the entire range between 1970 and 2009). This share was close to $40 \%$ in the 1970s, but has consistently been below $10 \%$ since 1996 .

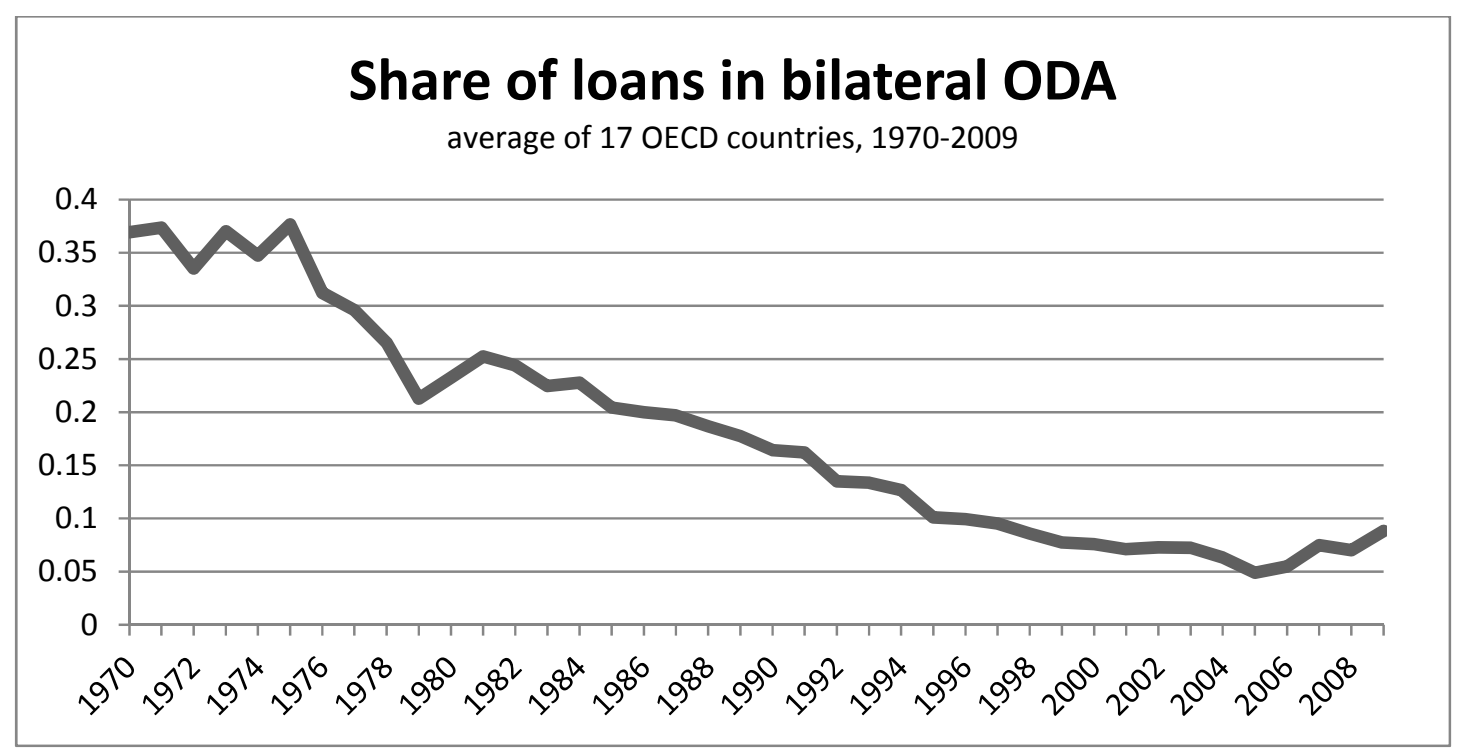

Figure 1. Source: OECD DAC questionnaire (2012 edition), Table 2A

The diminished share of loans in foreign aid has coincided with debates regarding its relative efficacy. President George W. Bush proposed in 2001 to raise the share of grant aid still further, but encountered resistance from European governments, who argued that such a shift may reduce overall aid resources and weaken recipient incentives to use aid resources prudently. Nunnenkamp et al. (2005) describe that this controversy was overblown, and that the real differences between grant and loan aid are in fact 
small. Goldstein and Moss (2005) show that the most surprising aspect of US aid policy under President George W. Bush were not changes in the composition of aid flows, but very generous overall US aid flows (in particular to Africa).

Despite this particular controversy, our prediction is that grant aid is more likely to exhibit partisan effects than loan aid (see also Odedokun 2003, 2004), as it is so closely analogous to domestic social welfare transfer payments. Grants may be more closely aligned with redistributive objectives than loans, which carry long-term repayment obligations. We also expect that partisan effects will be more visible in the grant time series, because loan payments are affected by additional confounds such as the risk of sovereign default, and the complex economics and politics of debt relief (Rajan 2005). ${ }^{7}$ The simple time series of annually extended loan payments are therefore likely to give an incomplete account of donor attitudes towards potential loan recipients.

\section{Aid by income group}

We separate recipient countries according to the standard UN socioeconomic development classification, which is also used by the OECD Development Co-operation Directorate for the member states of the Development Assistance Committee's (DAC). Recipient groups include least developed countries (LDCs), other low income countries (OLICs), lower middle income countries (LMICs), upper middle income countries (UMICS), and more advanced developing countries and territories (MADCTs). These sets of countries have been quite stable: for example, out of the countries originally designated as LDCs in 1971, only three have since "graduated" from that group; nevertheless, as a precaution we fix the sets of income groups, using their classification as of $2010 .{ }^{8}$ Based on our rationale for a partisan effect, we hypothesize that leftwing governments increase aid payments to less developed countries in

\footnotetext{
${ }^{7}$ Foreign aid has been shown to reduce debt repayment incentives in recipient countries (Bjørnskov and Schröder 2013).

${ }^{8}$ http://www.unohrlls.org/en/ldc/164/ (accessed on 19 June 2013)
} 
particular. ${ }^{9}$ We emphasize the groups of LDCS, LMICs, and UMICs; they represent a clear progression from poorer to less poor countries and therefore of relative "need". The remaining income groups are more problematic because they contain very few countries (six OLICs), or contain recipient countries not commonly counted as developing countries at all (e.g. South Korea, Singapore, and Israel are among MADCTS). LDCS, LMICS and UMICs together account for ca. $70 \%$ of donors' bilateral aid budgets on average.

\section{Political institutions}

We separate recipient countries by their political institutions using the democracy-dictatorship data by Cheibub et al. (2010). ${ }^{10}$ Cheibub et al. (2010) provide two measures for political institutions: a standard democracy variable, and a more expansive democracy measure which counts additional countries as democracies if they are characterized as multi-party systems, even if there are no changes in government coalitions that would indicate that power is in fact contestable. We include estimates for both democracy measures. We devise three ways of separating aid to democratic and to autocratic countries over our sample period: first, for each donor-year combination, we add all bilateral aid flows to democratic recipients, and all bilateral aid flows to autocratic countries. We use the sums as our dependent variables. This scheme has the advantage of being conceptually straightforward, but may cause problems due to the change of political institutions over time. A regime change in a large recipient country, for example, may generate large fluctuations in these time series that may falsely be attributed to a partisan effect. Our two remaining classifications therefore fix the set of democratic and autocratic

\footnotetext{
${ }^{9}$ Using data for the United States, the United Kingdom, France, and Japan, Warren (2012) demonstrates that rightwing governments in the United States and France gave less bilateral aid to least developed countries. For example, on 22 June, 1990, the leftwing French President François Mitterand "announced that his government would in the future donate rather than lend money to the world's 35 poorest countries, including 22 in SubSaharan Africa, and would reduce the interest rate paid on French loans by four African countries from 10 to 5 percent" (New York Times). http://www.nytimes.com/1990/06/22/world/france-ties-africa-aid-to-democracy.html (accessed on 05 October 2012).

${ }^{10}$ The data by Cheibub et al. (2010) are available till 2008.
} 
recipients over time. Our "static" variables include only recipients that were democratic or autocratic throughout the entire sample period (some recipients are consequently dropped altogether). Our final classification orders all recipients by their share of democratic years; recipients with above-median share of years under democratic institutions are counted as democratic recipients, and all others as autocratic recipients.

There is no clear-cut hypothesis on how donor ideology should influence aid to democracies and autocracies. It is conceivable that leftwing governments would like to increase aid to autocracies to induce economic and political reform (French President François Mitterand once promised "that French aid would in the future flow "more enthusiastically" to those countries that take steps toward democracy." ${ }^{11}$ ) On the other hand, politicians may not want to reward autocratic regimes by providing foreign aid.

\section{Tied vs. Untied Aid}

Since 1979, the OECD provides data on the "tying" status of foreign aid commitments. The tying status refers to the practice of donor countries to give aid conditional on that aid being spent on export goods from their own country. Foreign aid may thus become an instrument of industrial policy. This practice has gone mostly out of fashion around the end of the Cold War. From as much as $60 \%$ in the 1980 s, the average share of (at least partially) tied ODA commitments has fallen to around $10 \%$ in recent years. While of diminishing importance, it still comprises a significant share of overall ODA for a large section of our sample.

We expect that a partisan effect will be pronounced in the allocation of untied foreign aid. If foreign aid reflects a motivation to redistribute resources and alleviate poverty, elements of ODA that

\footnotetext{
${ }^{11}$ http://www.nytimes.com/1990/06/22/world/france-ties-africa-aid-to-democracy.html (accessed on 05 October 2012).
} 
are more closely connected to industrial policy will be less sensitive to ideological shifts in donor governments than elements that are purely redistributive. We are, however, agnostic as to the expected partisan effects on industrial policy. If it were true that leftwing governments were both prone to disburse aid more generously, and to engage in more export-promoting industrial policy, it would hinder the identification of a partisan effect on "tied" or "untied" aid.

\section{Aid by sector}

Donor countries also disaggregate their bilateral aid payments by "major purpose" or sector (see also Thiele et al. 2007). All figures thus reported are aggregated across all bilateral recipients, making it impossible to overlay the geographic distribution and the sector-specific distribution of aid flows. Taken together, sector-specific payments are a proper partition of total bilateral aid, because non-sector specific aid flows are assigned a "sector" (or "major purpose") code, too. Every component of bilateral aid is thereby accounted for, and no item is ever assigned multiple codes. As an example of non-sectorspecific aid, code 510 contains aid payments delivered as "general budget support" ${ }^{12}$ The sector-specific data can therefore serve to track changes that result from shifting donor priorities regarding the kinds of aid and the range of projects or policies within a recipient country that are deemed worthy of material support.

Any attempt to infer donor intentions or priorities from the distribution of aid over sectors is problematic. ${ }^{13}$ While payments to different sectors cannot overlap as a matter of accounting, the notion of discrete "major purposes" is not rich enough to map to the whole range of donor goals and motivations. Consider, for example, a donor government that reduces payments to the sector "110: Education", while increasing payments in the form of general budget assistance. One may infer that

\footnotetext{
${ }^{12}$ Code 998 captures also residual flows ("sector unspecified/not applicable").

${ }^{13}$ We are indebted to an anonymous referee for motivating the following caveats to interpreting sector-specific regression results.
} 
education has become a lesser priority in the donor's aid strategy vis-à-vis other sectors, say public health, or financial sector reform. Yet it is also possible that direct budget support may simply have become another mechanism for pursuing the priorities, including educational goals (e.g. recipient governments provide funding to students and schools). In general, aid flows to different sectors are unlikely to be independent, with complex substitution patterns between sectors. We use aid flows to distinct subsets of sectors as dependent variables to elucidate shifting donor priorities and per-sector partisan effects, but do not take into account the interdependence between sectors. The problem may be somewhat alleviated by selecting sector groups that are clearly delineated and each account for a substantial share of average donor aid budgets. Among these groups is the cluster "Commodity Aid and General Program Assistance", to gauge specifically the distinction between sector-specific and program aid. The remaining sector groups are: "Social Infrastructure and Services" (sectors 110-160), and its largest subset, "Education"; "Economic Infrastructure and Services" (210-250), which include transportation, communications, energy and financial infrastructure; "Production Sectors" (310-332), comprising both agricultural, manufacturing, and mining sectors; "General Environmental Protection" (410); "Commodity Aid and General Programme Assistance" (500), which contains all bilateral program aid; "Action relating to debt" (600); and "Humanitarian Aid" (720-740), including emergency response, reconstruction, and prevention.

We expect a partisan effect in those areas most closely associated with reducing poverty and socioeconomic inequality such as spending on education and public health, and on basic services and infrastructure such as sanitation (all included in "Social Infrastructure"). ${ }^{14}$

\footnotetext{
${ }^{14}$ Potrafke (2011) shows, for example, that leftwing governments have increased the growth of public spending on education in OECD countries; public spending in other areas, by contrast, do not display pronounced partisan effects.
} 


\section{Data and Empirical Approach}

\subsection{Data}

Data on foreign aid (ODA) are compiled by the DAC. There are two reporting channels by which data are collected: first, DAC member governments report annual aggregate aid flows directly to the OECD in a standardized format. Second, through the Creditor Reporting System (CRS), member states report their foreign aid activity at the level of individual projects. Despite its higher level of detail, the CRS is not suitable for our present purposes, due to its severely limited coverage especially of older data. ${ }^{15}$ We therefore draw our data from the DAC database exclusively.

The DAC data allow us to track each donor's annual aid activity by recipient (state or multilateral institution); by purpose or sector (e.g. infrastructure, education, humanitarian aid); and finally by tying status, which refers to stipulations that a specific disbursement of foreign aid must be spent on goods and services from the donor country. These three dimensions are reported separately by members of the DAC, making it impossible for us to intersect categories along different dimensions (e.g. we cannot determine the sector composition of aid to an individual recipient, or the share of tied aid to different sectors). ${ }^{16}$ In each case, we usually have separate information on commitments and disbursements, i.e. aid payments pledged for a particular year versus actual transfers. We can usually distinguish between grant aid (i.e. aid without repayment obligation) and aid in the form of concessionary loans.

\footnotetext{
${ }^{15}$ CRS data on both aid commitments and disbursements covered more than $90 \%$ of all aid since around 2002, but for aid disbursements the coverage is below $60 \%$ before that, while records of aid commitments covered around $70 \%$ of all aggregate aid commitments in 1995. See the User's Guide to the CRS, http://www.oecd.org/document/50/0,3746,en_2649_34447_14987506_1_1_1_1,00.html (accessed on 05 June 2012).

${ }^{16}$ See the DAC Statistical Reporting Directives, http://www.oecd.org/document/4/0,3746,en $264934447 \quad 19185321111$ 1,00.html (accessed on 05 June 2012).
} 
We pay particular attention to restrict the analysis to gross flows. Net flows of aid disbursements are significantly harder to interpret, since they often include negative components that are the result of decisions made in preceding years: net loans in particular include received interest payments as a consequence of previously extended loans, and as a result, overall flows are frequently negative. Since we want to measure the effect of government ideology on foreign aid decisions made during the tenure of an individual government, we focus on gross loans and grants.

The data comprises flows between 1960 and 2009 for 23 countries $^{17}$, but data availability is often more limited: some items in the DAC database were created in later years (for example, data on the tying status of aid is available from 1979), and some countries joined the DAC after 1960, or reported incomplete data series for some years. Our panels consequently do not always cover the whole time range, and are usually unbalanced.

There are also issues of data quality. The self-reporting mechanism ensures some degree of internal consistency of the data (e.g. the sum of aid across all sectors should equal the sum of aid across recipients), but the assignment of aid to various categories cannot be checked from within the data. The reported allocations of aid by sector, for example, may have limited precision and reliability (Dreher et al. 2008a). More fundamentally, all OECD aid data is under the caveat that they are self-reported by sovereign donor governments to a multilateral organization of their own making: ambiguity of the underlying definitions, complexity of internal government accounting systems, concerns with secrecy and national or government prestige, and a lack of strong incentives all suggest some degree of skepticism when interpreting results based on these data.

\footnotetext{
${ }^{17}$ The countries included are: Australia, Austria, Belgium, Canada, Denmark, Finland, France, Germany, Greece, Iceland, Ireland, Italy, Japan, Luxembourg, Netherlands, New Zealand, Norway, Portugal, Spain, Sweden, Switzerland, United Kingdom, and United States.
} 


\subsection{Empirical Model}

The baseline panel data model has the following form:

$\Delta \log$ foreign aid category $\mathrm{ijt}_{\mathrm{i} t}=\alpha_{\mathrm{j}}$ Ideology $_{\mathrm{it}}+\Sigma_{1} \beta_{\mathrm{j} 1} \Delta \log \mathrm{X}_{\mathrm{ilt}}+\eta_{\mathrm{i}}+\varepsilon_{\mathrm{t}}+\mathrm{u}_{\mathrm{ijt}}$

with $\mathrm{i}=1, \ldots, 23 ; \mathrm{j}=1, \ldots, 108 ; 1=1, \ldots, 3 ; \mathrm{t}=1, \ldots, 49$

The dependent variable $\Delta \log$ foreign aid category ${ }_{\mathrm{ijt}}$ denotes the growth rate of foreign aid spending in category $j$ (as a share of GDP) in country $i$ and year $t$. We use growth rates instead of levels to avoid spurious regression. The key explanatory variable Ideology $y_{\text {it }}$ denotes the ideological orientation of the corresponding donor government. We employ the government ideology index by Potrafke (2009), which is based on the index of governments' ideological positions by Budge et al. (1993) and updated by Woldendorp et al. $(1998,2000)$. This index places the cabinet on a left-right scale with categorical values between 1 (powerful rightwing) and 5 (powerful leftwing). $\Delta \log \mathrm{X}_{\mathrm{ilt}}$ contains three economic control variables: the growth rate of real GDP per capita, the growth rate of size of government (government expenditures as a share of GDP), and the growth rate of trade openness (sum of imports and exports as a share of GDP). For robustness tests, we also include foreign direct investment (sum of inflows and outflows as a share of GDP), public debt (as a share of GDP) and the KOF indices of globalization. We do not include foreign direct investment and the globalization indices in the baseline model because these variables are not available for the entire sample period 1960-2009. $\eta_{i}$ describes fixed country effects, $\varepsilon_{t}$ fixed period effects and $\mathrm{u}_{\mathrm{ijt}}$ is an error term. Table 1 provides descriptive statistics and sources of all variables included.

In contrast to Tingley (2010a), we regress the growth rate of the foreign aid spending categories on the government ideology variable in levels. This approach suggests that leftwing and rightwing governments 
implement their preferred policies incrementally, that is, step by step over the course of the legislative period. We estimate the model by ordinary least squares in a common fixed effects framework and standard errors robust to heteroskedasticity (Huber/White/sandwich standard errors - see Huber 1967, White 1980 and 1982, and Stock and Watson 2008).

\section{Results}

\subsection{Baseline results}

Table 2 shows the results for total, bilateral and multilateral ODA (commitment and disbursement). Government ideology did not influence the growth of spending on total ODA, bilateral and multilateral ODA. The coefficient of the ideology variable does not turn out to be statistically significant in columns (1) to (6). The control variables display the expected effects: the coefficient of the per capita GDP variable has a positive sign and is statistically significant at the $10 \%$ level in column (6). The numerical meaning of this effect is that when per capita GDP increases by $1 \%$, committed multilateral aid (as a share of GDP) increases by about $2.3 \%$. Per capita GDP does not turn out to be statistically significant in columns (1) to (5). The coefficient of the size of government variable has a positive sign and is statistically significant at the $5 \%$ level in column (2) and at the $10 \%$ level in columns (3) and (4); it lacks statistical significance in columns (1), (5) and (6). When government expenditures as a share of GDP increase by $1 \%$, total committed aid (as a share of GDP) increases by about $0.61 \%$; bilateral disbursed aid by about $0.47 \%$, and bilateral committed aid by $0.54 \%$. Donors with high per capita GDP and a large government thus provided more aid than donors with low per capita GDP and a small government in our sample. The trade variable does not turn out to be statistically significant in columns (1) to (6).

Table 3 shows the results for bilateral loans and grants. Government ideology did not influence loans. By contrast, government ideology influenced grants. The government ideology variable is 
statistically significant at the $5 \%$ level in columns (3) and (4). The coefficient of the government ideology variable has a positive sign and indicates that when the government ideology variable increases by two points - say from 2 (rightwing government) to 4 (leftwing government) - the growth rate of bilateral grants (disbursed) increases by about 3.9 percentage points and the growth rate of bilateral grants (committed) increases by about 4.0 percentage points.

We examine whether the positive influence of government ideology on bilateral grants depends on specific recipient country characteristics. Table 4 shows the results of committed bilateral aid flows to different recipient income groups. The coefficient of government ideology is statistically significant at the $5 \%$ level in column (6) and at the $1 \%$ level in column (8) and indicates that leftwing governments provided more aid (grants) to least developed countries and lower middle income countries than rightwing governments. The numerical meaning of the effect is that when the government ideology variable increases by two points the growth rate of committed aid to least income countries increases by about 8.4 percentage points and to lower middle income countries by about 8.3 percentage points. The coefficient of the government ideology variable does not turn out to be statistically significant in the other specifications. The regression results for disbursed bilateral aid flows also show that government ideology influenced bilateral aid to least income countries.

Table 5 shows the regression results of bilateral aid to democratic and autocratic recipient countries. Distinguishing between the standard and expansive democracy measure and between the three ways on how to group democratic and autocratic recipient countries (time-variant, static and static with median cutoff) gives rise to 72 regressions. We therefore only show the coefficient estimates of the government ideology variable and do not report the coefficient estimates of the control variables. The results show that inferences somewhat depend on how we measure political institutions, and on whether we use the time-variant or static measures. Again, bilateral grant payments display a significant partisan effect. The 
effect is more pronounced for autocratic recipient countries. In column (2), the coefficient estimate of the government ideology variable is significant at the $1 \%$ level in row (1) and (4), at the $5 \%$ level in row (2) and (6) and at the $10 \%$ level in row (5). The coefficient does not turn out to be statistically significant for the standard static democracy measure (row 3). By using the time-variant democracy measures and the standard static (median cutoff) democracy measure in columns (5) and (11), the estimates indicate a partisan effect for loans to democratic countries. At a higher level of aggregation (total ODA), there are hardly any significant partisan effects for total ODA flows, for neither democratic nor autocratic recipients, whether analyzing commitments or disbursements; an exception is column (10), rows (2) and (4) for the expansive democracy measure. Government ideology does not turn out to be statistically significant when we measure political institutions by the standard static democracy variable (row 3 ). The numerical meaning of the partisan effect is largest when we measure political institutions by the expansive static measure (row 4) as compared to the time-variant measures in rows (1) and (2) and the static median cutoff in rows (5) and (6). For example, when the government ideology variable increases by two points, the growth rate of committed grants to autocratic countries (column 2) is estimated to increase by about 7.1 percentage points in row (1), 8.3 percentage points in row (2), 19.1 percentage points in row (4), 6.5 percentage points in row (5), and 7.5 percentage points in row (6).

Table 6 shows the regression results of tied and untied bilateral aid. Leftwing governments increased the growth rate of grant aid - notwithstanding whether grant aid was tied, untied or partially tied. The coefficient estimates vary in magnitudes. When the government ideology variable increases by two points the growth rate of untied grant aid increases by about 12.6 percentage points (column 1 ), tied grant aid by about 24.1 percentage points (column 3), untied and partially tied grant aid by about 13.2 percentage points (column 5), and tied and partially tied grant aid by about 23.7 percentage points (column 7). The numerical meaning of the partisan effects on tied/untied grant aid are thus larger than 
the partisan effects on overall grants (Table 3). The samples using tied/untied aid as described in Table 6 are however about half as large as compared to the overall grants in Table 3.

Table 7 shows the results of bilateral aid by sector. The government ideology variable does not turn out to be statistically significant in any specification. This finding is consistent with the overall picture that emerged based on preceding regressions: partisan effects are centered on the grant element of bilateral aid. As we acknowledged in the description of our sector variables, the significant differences and overlapping objectives of sector aid and program aid makes it hard to interpret any of the coefficient estimates of the ideology variable in Table 7. Since we do not find any partisan effect throughout all columns, we need not examine this issue further. Our conclusion is that unlike in the case of tied vs. untied aid, breaking down bilateral aid along sector (or "major purpose") lines does not further narrow down the locus of the overall partisan effect observed throughout most grant aid regressions.

Overall, our results indicate a limited effect of government ideology on the allocation of foreign aid. The partisan effect is firmly centered on the bilateral grant element of foreign aid, and is reflected in the results for both commitment and disbursement data. In particular, grants to least developed countries and lower middle-income countries account for the bulk of the observed partisan effect. We hypothesized that partisan effects were most likely to affect grant aid, based on the analogy to domestic social welfare transfer payments; similarly, the particular concern for alleviating poverty and inequality on the political left suggests that if ideology sways national foreign aid policies, it should most strongly affect aid to recipient countries with the greatest "need", i.e. poor countries. The pattern of the coefficient estimates in our regressions conforms to these hypotheses. It also supports Tingley's (2010a) result that ideology affects aid commitments to least developed countries (contrary to the results in 
Round and Odedokun 2004). But our results show that this effect is more localized and mainly affects bilateral grant aid.

\subsection{Robustness checks}

We have tested the robustness of our estimates in several ways. Our results could be sensitive to our choice of government ideology index. Therefore, we have replaced Potrafke's (2009) government ideology index with the alternative one by Bjørnskov (2008a) which is based on the Henisz (2000) database on political outcomes since the 19th century, and the general approach to measuring political ideology follows Bjørnskov (2005, 2008b). Contrary to the index employed in Bjørnskov (2005, 2008b), however, the Bjørnskov (2008a) index explicitly "takes the social democratic party in a given country as an internationally comparable anchor around which other parties are placed on a five-point scale (-1; $.5 ; 0 ; .5 ; 1$ ) from left to right" (Bjørnskov 2008a: p. 5). The Bjørnskov (2008a) index stresses the potential importance of the domestic political environment, in particular whether governments have a majority in parliament or not. We have also replaced government ideology in period t by government ideology in period $\mathrm{t}-1$ because governments may need some time to implement their preferred policies due to general bureaucratic inertia. We performed all previous regressions using Potrafke's government ideology index lagged by one period, and using Bjørnskov's government ideology index (both with and without lag). The results show that leftwing governments increased the growth of bilateral grants. In particular, leftwing governments increased spending to least income countries. These two results are robust to various specifications. When we measure government ideology by the lagged ideology indices, the results indicate that leftwing governments also increased overall bilateral and multilateral aid.

We also included the growth rate of foreign direct investment (sum of inflows and outflows as a share of GDP) and public debt as a share of GDP. We replaced the growth rate of trade-openness with the growth rate of the KOF index of globalization (Dreher 2006, Dreher et al. 2008c). The KOF index of 
globalization is available since 1970. FDI, debt and the KOF index do not, however, turn out to be statistically significant in nearly any specification, and including these variables does not change our inferences regarding the partisan effects with one exception: when we include the KOF index or run the baseline model since 1970, the results show that leftwing governments decreased the growth of loan aid to least income countries. This finding perfectly corresponds with our result that leftwing governments increased the growth of bilateral grant aid to least developed countries.

The reported effects may depend on idiosyncratic circumstances in individual countries. We have therefore tested whether our results are sensitive to the exclusion of individual countries. For bilateral grants, the influence of government ideology declines somewhat when Denmark and the United Kingdom are excluded, while increasing when Norway and especially the United States are excluded. The effect induced by excluding the United States is driven to a large extent by the presidency of George W. Bush. Overall, however, the inclusion/exclusion of any individual country does not change our general inferences about the effects of government ideology on the components of foreign aid.

We acknowledge that we cannot eliminate any concerns about reverse causality between foreign aid spending and government ideology. Eliminating any concerns about reverse causality would require, for example, using a valid instrumental variable for government ideology. We do not have such a valid instrumental variable. We believe however that foreign aid policy does not cause governing parties to be elected out of office. Voters are more concerned about domestic policies such as spending on social affairs which encompass a much larger share of a government's budget than foreign aid. 


\section{Conclusion}

We examine how donor government ideology influences types of foreign aid flows. We propose that foreign aid provides an important test case for partisan politics, due to its small overall share of donor government budgets, and the remoteness of its beneficiaries (relative to government constituencies).

Using disaggregated flow variables, the results show a localized partisan effect on the growth rates of foreign aid: It is centered on bilateral grant aid, and more specifically on grant aid to less developed countries. Our more localized result thus resolves the different results of Round and Odedokun (2004), who find no partisan effect at all, and Chong and Gradstein (2008) and Tingley (2010a), who find a partisan effect in total aid. Our findings also confirm our initial hypotheses that a potential partisan effect would be strongest for grants (which are more akin to domestic social welfare transfer payments), and for less developed country recipients (where poverty and inequality are of greatest concern). Leftwing governments tended to give more aid to autocratic as compared to democratic recipient countries. Our results regarding foreign aid provision to autocratic versus democratic countries depend however on how we measure political institutions and on how we group aid to democratic versus autocratic countries. Future research may therefore elaborate in more detail on ideology-induced aid policies by using various indicators of political institutions.

\section{Acknowledgments}

We would like to thank Christian Bjørnskov, Axel Dreher, Björn Kauder, Stephen Knack, Marina Riem, Jennifer Tobin, Heinrich Ursprung, the participants of the Political Economy of International Organizations Conference 2010 and the European Public Choice Society Meeting 2010, and two anonymous referees for their very helpful comments, hints, and suggestions. We are also grateful to David Happersberger, Danny Kurban and Ha Quyen Ngo for their excellent research assistance. 


\section{References}

Abbas, Ali A., Belhocine, Nazim, El-Ganainy, Asmaa, Horton, Mark, 2010. A Historical Public Debt Database. IMF Working Paper WP/10/245, Washington, DC.

Alesina, Alberto, Dollar, David, 2000. Who gives foreign aid to whom and why? Journal of Economic Growth 5(1), 33-63.

Arellano, Cristina, Bulir, Ales, Lane, Timothy, Lipschitz, Leslie, 2009. The dynamic implications of foreign aid and its variability. Journal of Development Economics 88(1), 87-102.

Berthélemy, Jean-Claude, Tichit, Ariane, 2004. Bilateral donors' aid allocation decisions-a threedimensional panel analysis. International Review of Economics and Finance 13(3), 253-274.

Berthélemy, Jean-Claude, 2006. Bilateral donors' interest vs. recipients' development motives in aid allocation: do all donors behave the same? Review of Development Economics 10(2), 179-194.

Bjørnskov, Christian, 2005. Does political ideology affect economic growth? Public Choice 123(2), 133146.

Bjørnskov, Christian, 2008a. Political ideology and the structure of national accounts in the Nordic countries, 1950-2004. Paper presented at the annual meeting of the European Public Choice Society, Jena 27-30 March 2008.

Bjørnskov, Christian, 2008b. The growth-inequality association: government ideology matters. Journal of Development Economics 87(2), 300-308.

Bjørnskov, Christian, 2010. Do elites benefit from democracy and foreign aid in developing countries? Journal of Development Economics 92(2), 115-124.

Bjørnskov, Christian, Schröder, Philipp, 2013. Are debt repayment incentives undermined by foreign aid? Journal of Comparative Economics, forthcoming.

Blair, Patricia W., 1969. The dimension of poverty. International Organization 23(Summer), 683-704.

Boone, Peter, 1996. Politics and the effectiveness of foreign aid. European Economic Review 40(2), 289329.

Boschini, Anne, Olofsgard, Anders, 2002. Foreign aid: an instrument for fighting poverty or communism? Journal of Development Studies 43(4), 622-648.

Budge, lan, Keman, Hans, Woldendorp, Jaap, 1993. Political data 1945-1990. Party government in 20 democracies. European Journal of Political Research 24(1), 1-119. 
Buffie, Edward, Adam, Christopher, O'Connell, Stephen, Pattillo, Catherine, 2009. Fiscal inertia, donor credibility, and the monetary management of aid surges. Journal of Development Economics 93(2), 287298.

Cheibub, José A., Gandhi, Jennifer, Vreeland, James R., 2010. Democracy and dictatorship revisited. Public Choice 143(1-2), 67-101.

Chong, Alberto, Gradstein, Mark, 2008. What determines foreign aid? The donors' perspective. Journal of Development Economics 87(1), 1-13.

Chong, Alberto, Gradstein, Mark, Calderon, Cecilia, 2009. Can foreign aid reduce income inequality and poverty? Public Choice 140(1), 59-84.

Collier, Paul, Hoeffler, Anke, 2004. Aid, policy and growth in post-conflict societies. European Economic Review 48(5), 1125-1145.

Doucouliagos, Hristos, Paldam, Martin, 2008. Aid effectiveness on growth: a meta study. European Journal of Political Economy 24(1), 1-24.

Doucouliagos, Hristos, Paldam, Martin, 2011. The ineffectiveness on development aid on growth: An update. European Journal of Political Economy 27(2), 399-404.

Dreher, Axel, 2006. Does globalization affect growth? Evidence from a new index of globalization. Applied Economics 38(1), 1091-1110.

Dreher, Axel, Nunnenkamp, Peter, Schmaljohann, Maya, 2013. The allocation of German aid: selfinterest and government ideology. Kiel Working Papers No. 1817.

Dreher, Axel, Nunnenkamp, Peter, Thiele, Rainer, 2008a. Does aid for education educate children? Evidence from panel data. World Bank Economic Review 22(2), 291-314.

Dreher, Axel, Nunnenkamp, Peter, Thiele, Rainer, 2008b. Does US aid buy UN General Assembly votes? A disaggregated analysis. Public Choice 136(1), 139-164.

Dreher, Axel, Gaston, Noel, Martens, Pim, 2008c. Measuring globalization - Gauging its consequences. Berlin: Springer.

Epstein, Gil S., Gang, Ira N., 2009. Good governance and good aid allocation. Journal of Development Economics 89(1), 12-18.

Fleck, Robert K., Kilby, Christopher, 2001. Foreign aid and domestic politics: Voting in Congress and the allocation of USAID contracts across Congressional districts. Southern Economic Journal 67(3), 598-617.

Fleck, Robert K., Kilby, Christopher, 2006. How do political changes influence US bilateral aid allocations? Evidence from panel data. Review of Development Economics 10(2), 210-223. 
Fleck, Robert K., Kilby, Christopher, 2010. Changing aid regimes? U.S. foreign aid from the Cold War to the War on Terror. Journal of Development Economics 91(2), 185-197.

Fuchs, Andreas, Dreher, Axel, Nunnenkamp, Peter, 2012. Determinants of donor generosity: A survey of the aid budget literature. Courant Research Centre Poverty, Equity and Growth - Discussion Paper s121. Göttingen.

Goldstein, Markus, Moss, Todd, 2005. Compassionate conservatives or conservative compassionates? US political parties and bilateral foreign assistance to Africa. Journal of Development Studies 41(7), 1288-1302.

Gupta, Sanjeev, Clements, Benedict, Pivovarsky, Alexander, Tiongson, Erwin R., 2003. Foreign aid and revenue response: does the composition of aid matter? IMF Working Paper 03/176.

Henisz, Witold J., 2000. The institutional environment for growth. Economics and Politics 12(1), 1-31.

Huber, Peter J., 1967. The behavior of maximum likelihood estimates under nonstandard conditions. Proceedings of the Fifth Berkeley Symposium on Mathematical Statistics and Probability, 221-233.

Imbeau, Louis M., 1988. Aid and ideology. European Journal of Political Research 16(1), 3-28.

Kilby, Christopher, Dreher, Axel, 2010. The Impact of aid on growth revisited: do donor motives matter? Economics Letters 107(3), 338-340.

Knack, Stephen, Rahman, Aminur, 2007. Donor fragmentation and bureaucratic quality in aid recipients. Journal of Development Economics 83(1), 176-197.

Kuziemko, llyana, Werker, Eric, 2006. How much is a seat on the Security Council worth? Foreign aid and bribery at the United Nations. Journal of Political Economy 114(5), 905-930.

Lumsdaine, David H., 1993. Moral vision in international politics: the foreign aid regime, 1949-1989.

Princeton University Press, Princeton.

Lundsgaarde, Erik, Breunig, Christian, Prakash, Aseem, 2007. Trade versus aid: donor generosity in an era of globalization. Policy Sciences 40(2), 157-179.

Maizels, Alfred, Nissanke, Machiko K., 1984. Motivations for aid to developing countries. World Development 12(9), 879-900.

Mascarenhas, Raechelle, Sandler, Todd, 2006. Do donors cooperatively fund foreign aid? Review of International Organizations 1(4), 337-357.

McGillivray, Marc, Feeny, Simon, Hermes, Niels, Lensink, Robert, 2005. It works; it doesn't; it can, but that depends. 50 years of controversy over the macroeconomic impact of development aid. WIDER Research Paper, 2005/54. 
McKinlay, Robert D., Little, Richard, 1977. A foreign policy model of US bilateral aid allocation. World Politics 30(1), 58-86.

McKinlay, Robert D., Little, Richard, 1978. A foreign-policy model of the distribution of British bilateral aid, 1960-70. British Journal of Political Science 8(3), 313-331.

Meernik, James, Krueger, Eric L., Poe, Steven C., 1998. Testing models of US foreign policy: foreign aid during and after the Cold War. Journal of Politics 60(1), 63-85.

Milner, Helen V., Tingley, Dustin H., 2010. The political economy of U.S. foreign aid: American legislators and the domestic politics of aid. Economics and Politics 22(2), 200-232.

Milner, Helen V., Tingley, Dustin H., 2011. Who supports global economic engagement? The sources of preferences in American economic policy. International Organization 65(1), 37-68.

Milner, Helen V., Tingley, Dustin H., 2013. The choice for multilaterism: Foreign aid and American foreign policy. Review of International Organizations, forthcoming.

Noël, Alain, Thérien, Jean-Philippe, 1995. From domestic to international justice: the welfare state and foreign aid. International Organization 49(Summer), 523-553.

Noël, Alain, Thérien, Jean-Philippe, 2008. Left and right in global politics. Cambridge University Press, Cambridge.

Nunnenkamp, Peter, Thiele, Rainer, Wilfer, Tom, 2005. Grants versus loans: much ado about (almost) nothing. Kiel Institute for World Economics, http://www.econstor.eu/bitstream/10419/3734/1/kepp04.pdf

Odedokun, Matthew, 2003. Economics and politics of official loans versus grants: panoramic issues and empirical evidence. WIDER Discussion Paper WPD, 2003/04.

Odedokun, Matthew, 2004. Multilateral and bilateral loans versus grants: issues and evidence. World Economy 27(2), 239-263.

Osterloh, Steffen, 2012. Words speak louder than actions: The impact of politics on economic performance. Journal of Comparative Economics 40(3), 318-336.

Ouattara, Bazoumana, Strobl, Eric A., 2008. Aid, policy and growth: does aid modality matter? Review of World Economics 144(2), 347-365.

Paxton, Pamela, Knack, Stephen, 2012. Individual and country-level factors affecting support for foreign aid. International Political Science Review 33(2), 171-192.

Potrafke, Niklas, 2009. Did globalization restrict partisan politics? An empirical evaluation of social expenditures in a panel of OECD countries. Public Choice 140(1-2), 105-124. 
Potrafke, Niklas, 2011. Does government ideology influence budget composition? Empirical evidence from OECD countries. Economics of Governance 12(2), 101-134.

Potrafke, Niklas, 2012. Political cycles and economic performance in OECD countries: empirical evidence from 1951-2006. Public Choice 151(1-2), 155-179.

Potrafke, Niklas, Ursprung, Heinrich W., 2013. Development aid as expressive giving. Paper presented at the European Public Choice Society Meeting 2013, Zurich.

Rajan, Raghuram, 2005. Debt Relief and Growth: How to craft an optimal debt relief proposal. Finance and Development 42(2), 56.

Rioux, Jean-Sébastien, Van Belle, Douglas A., 2005. The influence of le Monde coverage on French foreign aid allocations. International Studies Quarterly 49(3), 481-502.

Round, Jeffrey I., Odedokun, Matthew, 2004. Aid efforts and its determinants. International Review of Economics and Finance 13(3), 293-309.

Schraeder, Peter J., Hook, Stephen W., Taylor, Bruce, 1998. Clarifying the foreign aid puzzle: a comparison of American, Japanese, French and Swedish aid flows. World Politics 50(2), 294-323.

Stock, James H., Watson, Mark W., 2008. Heteroskedasticity-robust standard errors for fixed effect panel data regression. Econometrica 76(1), 155-174.

Summers, Robert, Heston, Alan, 1991. The Penn World Table (Mark 5): An expanded set of international comparisons, 1950-1988. Quarterly Journal of Economics 106, 327-369.

Thérien, Jean-Philippe, Noël, Alain, 2000. Political parties and foreign aid. American Political Science Review 94(1), 151-162.

Thiele, Rainer, Nunnenkamp, Peter, Dreher, Axel, 2007. Do donors target aid in line with the Millennium Development Goals? A sector perspective of aid allocation. Review of World Economics 143(4), 596-630.

Tingley, Dustin H., 2010a. Donors and domestic politics: political influences on foreign aid effort. Quarterly Review of Economics and Finance 50(1), 40-49.

Tingley, Dustin H., 2010b. Corrigendum to Donors and domestic politics: political influences on foreign aid effort. Quarterly Review of Economics and Finance 50(2), 244.

Tsoutsoplides, Constantine, 1991. The determinants of the geographical allocation of EC aid to the developing countries. Applied Economics 23(4), 647-658.

Wang, Yu, Jin, Shuai, 2013. Veto players and foreign aid provision. Constitutional Political Economy 24(1), 43-56. 
Warren, Dave, 2012. Bilateral aid to least developed countries: A study of the U.S., the U.K., France and Japan. The Park Place Economist 20(1), 94-102.

White, Halbert, 1980. A heteroskedasticity-consistent covariance matrix estimator and a direct test for heteroskedasticity. Econometrica 48(4), 817-838.

White, Halbert, 1982. Maximum likelihood estimation of misspecified models. Econometrica 50(1), 1-25.

Woldendorp, Japp, Keman, Hans, Budge, lan, 1998. Party government in 20 democracies: an update 1990-1995. European Journal of Political Research 33(1), 125-164.

Woldendorp, Japp, Keman, Hans, Budge, lan, 2000. Party government in 48 democracies 1945-1998: composition, duration, personnel. Dordrecht: Kluwer Academic Publishers.

Younas, Javed, 2008. Motivation for bilateral aid allocation: altruism or trade benefits. European Journal of Political Economy 24(3), 661-674. 
Table 1. Descriptive Statistics.

\begin{tabular}{|c|c|c|c|c|c|c|c|c|c|c|c|}
\hline \multirow{2}{*}{$\begin{array}{l}\text { ODA Variable (Source: OECD DAC database) } \\
\text { (all values in constant } 2010 \text { US dollars) }\end{array}$} & \multirow[t]{2}{*}{$\begin{array}{l}\text { Included Aid } \\
\text { Components }\end{array}$} & \multicolumn{5}{|c|}{ Commitments } & \multicolumn{5}{|c|}{ Disbursements } \\
\hline & & Obs. & Mean & Std. Dev. & Min. & Max. & Obs. & Mean & Std. Dev. & Min. & Max. \\
\hline Overall Aid & gross total ODA & 829 & 4514.315 & 5678.442 & 34.86 & 36002.14 & 973 & 3811.734 & 4999.043 & 1.37 & 31910.42 \\
\hline \multirow{3}{*}{ Aid to Bilateral Recipients } & gross total ODA & 829 & 3361.144 & 4713.11 & 4.39 & 31960.68 & 970 & 2875.074 & 4134.226 & 1.24 & 29287.7 \\
\hline & grants & 824 & 2415.61 & 3618.19 & 4.39 & 31957.83 & 967 & 2107.198 & 3177.364 & 1.24 & 29239.88 \\
\hline & gross loans & 632 & 1244.846 & 2260.085 & 0.45 & 13612.62 & 754 & 996.2312 & 1740.774 & 0.08 & 9254.66 \\
\hline $\begin{array}{l}\text { Aid to Multilateral Recipients } \\
\qquad \text { By Income Group: }\end{array}$ & gross total ODA & 794 & 1203.99 & 1248.757 & 15.38 & 6733.91 & 875 & 1051.424 & 1151.408 & 1.09 & 6700.2 \\
\hline Aid to Least Developed Countries (LDCs) & grants & 809 & 637.808 & 893.3595 & 0.08 & 11260.31 & 930 & 554.1275 & 724.6392 & 0.34 & 8188.46 \\
\hline Aid to Other Low Income Countries (OLICs) & grants & 798 & 238.604 & 422.4921 & -0.08 & 3681.04 & 896 & 231.9408 & 441.1613 & 0.02 & 3552.33 \\
\hline Aid to Lower Middle-Income Countries (LMICs) & grants & 812 & 690.2195 & 1497.424 & 0.03 & 21695.56 & 937 & 620.871 & 1222.389 & 0.13 & 16475.82 \\
\hline Aid to Upper Middle-Income Countries (UMICs) & grants & 797 & 156.6441 & 234.9356 & 0.03 & 1953.91 & 911 & 146.3765 & 235.5535 & 0.03 & 2131.13 \\
\hline Aid to MADCTs & grants & 543 & 174.2099 & 505.6075 & 0.01 & 3787.05 & 719 & 158.9849 & 471.4984 & 0.01 & 3859.2 \\
\hline Aid to Least Developed Countries (LDCs) & loans & 472 & 174.7472 & 274.6197 & -14.47 & 1584 & 576 & 137.8772 & 217.7721 & -13.83 & 1465.03 \\
\hline Aid to Other Low Income Countries (OLICs) & loans & 447 & 222.6801 & 436.2356 & -0.59 & 6081.08 & 558 & 155.1623 & 246.2881 & -0.28 & 1499.51 \\
\hline Aid to Lower Middle-Income Countries (LMICs) & loans & 578 & 803.919 & 1563.653 & 0.01 & 9633.74 & 678 & 613.209 & 1171.97 & -20.28 & 7819.6 \\
\hline Aid to Upper Middle-Income Countries (UMICs) & loans & 447 & 186.6977 & 326.1691 & 0.01 & 2883.11 & 575 & 172.7984 & 320.8498 & -1.85 & 2956.91 \\
\hline $\begin{array}{l}\text { Aid to MADCTs } \\
\qquad \text { By Political Institutions (time variant) }^{18}\end{array}$ & loans & 191 & 199.0909 & 305.3238 & 0 & 2064.35 & 252 & 157.8831 & 228.6844 & 0.01 & 1471.08 \\
\hline Democratic Countries & grants & 805 & 570.4051 & 1020.185 & 0 & 7589.58 & 923 & 524.9473 & 954.2643 & 0 & 7442.46 \\
\hline Autocratic Countries & grants & 805 & 1076.726 & 1796.195 & 0 & 21212.05 & 923 & 966.7762 & 1500.907 & 0 & 19423.21 \\
\hline Democratic Countries & total & 805 & 907.4833 & 1584.204 & 0 & 12016.97 & 923 & 819.8719 & 1449.94 & 0 & 8929.95 \\
\hline Autocratic Countries & total & 805 & 1670.329 & 2471.216 & 0 & 21772.34 & 923 & 1421.58 & 2059.984 & 0 & 19437.45 \\
\hline Democratic Countries (expansive) & grants & 805 & 943.3782 & 1825.6 & 0 & 24893.7 & 923 & 833.4755 & 1485.039 & 0 & 12516.46 \\
\hline Autocratic Countries (expansive) & grants & 805 & 703.7526 & 1096.193 & 0 & 14168.63 & 923 & 658.248 & 1040.913 & 0 & 15244.52 \\
\hline
\end{tabular}

\footnotetext{
${ }^{18}$ We use the data by Cheibub et al. (2010) to distinguish by political institutions.
} 


\begin{tabular}{|l|l} 
Democratic Countries (expansive) & total \\
Autocratic Countries (expansive) & total \\
Democratic Countries & \\
Autocratic Countries & grants \\
Democratic Countries & grants \\
Autocratic Countries & total \\
Democratic Countries (expansive) & total \\
Autocratic Countries (expansive) & grants \\
Democratic Countries (expansive) & grants \\
Autocratic Countries (expansive) & total \\
By Political Institutions (static, median-cutoff) & total \\
Democratic Countries & grants \\
Autocratic Countries & grants \\
Democratic Countries & total \\
Autocratic Countries & total \\
Democratic Countries (expansive) & \\
Autocratic Countries (expansive) & grants \\
Democratic Countries (expansive) & grants \\
Autocratic Countries (expansive) & total \\
total
\end{tabular}

\begin{tabular}{rrrrr|rrrrr}
805 & 1441.86 & 2505.395 & 0 & 25779.93 & 923 & 1254.681 & 2126.695 & 0 & 20609.7 \\
805 & 1135.952 & 1652.337 & 0 & 14189.52 & 923 & 986.7703 & 1442.716 & 0 & 15254.32 \\
& & & & & & & & & \\
& & & & & & & & & \\
805 & 215.3264 & 494.2773 & -22.74 & 4311.74 & 918 & 212.0049 & 512.7106 & 0 & 4149.41 \\
805 & 732.2888 & 1516.33 & 0 & 20122.31 & 918 & 640.4811 & 1174.339 & 0 & 17657.38 \\
805 & 354.6489 & 672.6485 & -22.74 & 5248.24 & 918 & 344.3815 & 713.4717 & 0 & 6040.37 \\
805 & 1046.836 & 1835.081 & 0 & 20605.57 & 918 & 875.3241 & 1462.516 & 0 & 17667.18 \\
& & & & & & & & & \\
805 & 277.0483 & 555.7122 & -1.36 & 4459.73 & 918 & 264.8113 & 555.0527 & 0 & 4300.82 \\
805 & 221.6371 & 733.2300 & 0 & 11534.02 & 918 & 193.0363 & 628.0244 & 0 & 13136.1 \\
805 & 450.4698 & 775.7243 & -1.36 & 5492.88 & 918 & 424.6020 & 786.4362 & 0 & 6418.21 \\
805 & 351.9330 & 924.0210 & 0 & 11545.11 & 918 & 286.0461 & 763.2587 & 0 & 13136.1 \\
& & & & & & & & & \\
& & & & & & & & & \\
805 & 786.6559 & 1176.349 & 0 & 8919.79 & 923 & 691.1301 & 1180.633 & 0 & 9019.42 \\
805 & 860.4748 & 1680.92 & 0 & 20402.13 & 923 & 800.5934 & 1363.861 & 0 & 19382.43 \\
805 & 1369.263 & 2181.329 & 0 & 17484.01 & 923 & 1096.513 & 1855.524 & 0 & 14201.5 \\
805 & 1208.549 & 2026.206 & 0 & 20905.59 & 923 & 1144.938 & 1785.814 & 0 & 19396.67 \\
& & & & & & & & & \\
805 & 788.7879 & 1515.234 & 0 & 25035.34 & 923 & 725.5389 & 1333.977 & 0 & 12603.06 \\
805 & 858.3429 & 1540.613 & 0 & 18275.84 & 923 & 766.1846 & 1301.928 & 0 & 18453.4 \\
805 & 1329.293 & 2327.268 & 0 & 25908.63 & 923 & 1187.432 & 2106.776 & 0 & 20891.78 \\
805 & 1248.52 & 1966.084 & 0 & 18302.17 & 923 & 1054.019 & 1625.74 & 0 & 18468.64
\end{tabular}




\begin{tabular}{|c|c|c|c|c|c|c|c|}
\hline \multirow{2}{*}{$\begin{array}{l}\text { ODA Variable (Source: OECD DAC database) } \\
\text { (all values in constant } 2010 \text { US dollars) }\end{array}$} & \multirow[t]{2}{*}{$\begin{array}{l}\text { Included Aid } \\
\text { Components }\end{array}$} & \multicolumn{5}{|c|}{ Commitments } & \\
\hline & & Obs. & Mean & Std. Dev. & Min. & Max. & \\
\hline Tied/Untied aid & & & & & & & \\
\hline Untied aid & grants & 538 & 1072.877 & 1988.968 & 0.85 & 21517.44 & \\
\hline Untied aid & loans & 314 & 810.2072 & 2002.097 & 0 & 10782.66 & \\
\hline Tied aid & grants & 491 & 428.9707 & 864.1161 & 0.04 & 8296.14 & \\
\hline Tied aid & loans & 278 & 284.3368 & 382.6735 & 0.23 & 1666.69 & \\
\hline Untied and partially tied aid & grants & 538 & 1136.072 & 2051.227 & 0.85 & 21517.44 & \\
\hline Untied and partially tied aid & loans & 318 & 863.9803 & 2091.912 & 0.11 & 10900.45 & \\
\hline Tied and partially tied aid & grants & 501 & 488.2707 & 982.6589 & 0.04 & 8296.14 & \\
\hline Tied and partially tied aid & loans & 288 & 345.0913 & 425.1214 & 0.33 & 1805.64 & \\
\hline By Sector: & & & & & & & \\
\hline Social infrastructure and services & total ODA & 780 & 997.0222 & 1673.936 & 2.74 & 16358.51 & \\
\hline Education & total ODA & 734 & 379.5851 & 645.3089 & 1.07 & 4167.55 & \\
\hline Economic Infrastructure and Services & total ODA & 773 & 576.9036 & 1124.33 & 0.05 & 7953.95 & \\
\hline Production Sectors & total ODA & 789 & 473.8274 & 681.5054 & 0.76 & 4068.62 & \\
\hline General Environmental Protection & total ODA & 309 & 90.99676 & 137.8915 & 0.04 & 891.94 & \\
\hline Program Assistance & total ODA & 725 & 417.6292 & 1026.159 & 0.03 & 9092.3 & \\
\hline Action Relating to Debt & total ODA & 541 & 451.8568 & 1161.741 & -2.36 & 17957.41 & \\
\hline Humanitarian Aid & total ODA & 703 & 160.9464 & 423.1481 & -81.1 & 4754.8 & \\
\hline Independent Variable & & Obs. & Mean & Std. Dev. & Min. & Max. & Source \\
\hline Ideology Index (leftwing) & & 1101 & 2.856494 & 0.8787005 & 1 & 4 & Potrafke (2009) \\
\hline Ideology Index (rightwing) & & 1101 & 0.3223777 & .3525948 & -0.566869 & 1 & Bjørnskov (2008a) \\
\hline Real GDP (per capita) & & 1140 & 23677.53 & 10033.54 & 4023.212 & 89814.01 & Penn World Tables 7.0 \\
\hline
\end{tabular}




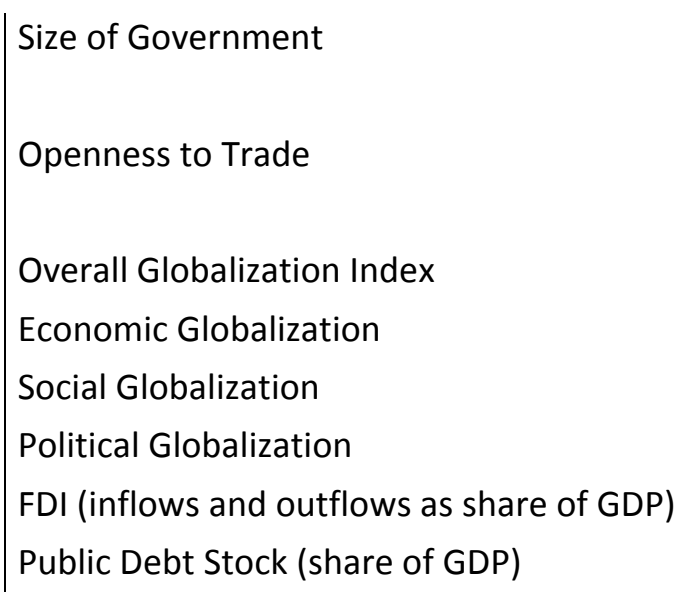

$\begin{array}{rrrrrrr}1140 & 7.175991 & 1.84208 & 1.72 & 13.33 & \begin{array}{r}\text { Penn World Tables 7.1 } \\ \text { Summers and Heston (1991) }\end{array} \\ 1140 & 54.70432 & 44.59266 & 7.46 & 326.54 & \begin{array}{r}\text { Penn World Tables 7.1 } \\ \text { Summers and Heston (1991) }\end{array} \\ 920 & 73.16154 & 12.16195 & 34.43336 & 92.83596 & \text { Dreher (2006), Dreher et al. (2008c) } \\ 920 & 69.69885 & 15.97288 & 21.37737 & 98.87576 & \text { Dreher (2006), Dreher et al. (2008c) } \\ 920 & 69.29912 & 14.33274 & 28.95484 & 91.43437 & \text { Dreher (2006), Dreher et al. (2008c) } \\ 920 & 83.47313 & 13.84437 & 39.65474 & 98.56072 & \text { Dreher (2006), Dreher et al. (2008c) } \\ 738 & 12.23706 & 75.79318 & -15.32823 & 1095.278 & \text { Worldbank (2012) } \\ 1093 & 48.08212 & 29.86037 & 1.716682 & 216.3484 & \text { Abbas et al. (2010) }\end{array}$


Table 2: Regression Results.

Total (gross) ODA vs. Multilateral ODA vs. Bilateral ODA (disbursement/commitment).

Dependent variable: $\Delta$ log Foreign Aid payment of category j (as a share of GDP).

OLS with standard errors robust to heteroskedasticity (Huber/White/sandwich standard errors).

\begin{tabular}{|c|c|c|c|c|c|c|}
\hline & (1) & $(2)$ & (3) & (4) & (5) & (6) \\
\hline & $\begin{array}{c}\text { Total } \\
\text { disbursed }\end{array}$ & $\begin{array}{c}\text { Total } \\
\text { committed }\end{array}$ & $\begin{array}{l}\text { Bilateral } \\
\text { disbursed }\end{array}$ & $\begin{array}{c}\text { Bilateral } \\
\text { committed }\end{array}$ & $\begin{array}{l}\text { Multilateral } \\
\text { disbursed }\end{array}$ & $\begin{array}{l}\text { Multilateral } \\
\text { committed }\end{array}$ \\
\hline \multirow[t]{2}{*}{ Ideology (leftwing) } & 0.0003 & -0.0003 & 0.0109 & 0.0119 & -0.0007 & -0.0157 \\
\hline & $(0.0095)$ & $(0.0115)$ & $(0.0097)$ & $(0.0131)$ & (0.0079) & $(0.0106)$ \\
\hline \multirow[t]{2}{*}{$\Delta$ log GDP per capita (real) } & -0.0072 & 0.8682 & 0.2833 & 0.4568 & -0.4498 & $2.2828^{*}$ \\
\hline & $(0.5479)$ & $(0.5140)$ & $(0.6384)$ & $(0.5823)$ & $(0.6446)$ & $(1.2628)$ \\
\hline \multirow[t]{2}{*}{$\Delta \log$ Size of Government } & 0.3527 & $0.6070 * *$ & $0.4713^{*}$ & $0.5372^{*}$ & 0.2470 & 0.8506 \\
\hline & $(0.2778)$ & $(0.2371)$ & $(0.2346)$ & $(0.3016)$ & $(0.3020)$ & $(0.5672)$ \\
\hline \multirow[t]{2}{*}{$\Delta \log$ Trade } & -0.4717 & -0.0015 & -0.0350 & 0.2422 & -0.4455 & 0.3365 \\
\hline & $(0.3050)$ & $(0.3729)$ & $(0.4943)$ & $(0.5097)$ & $(0.5114)$ & $(0.4721)$ \\
\hline Fixed country effects & Yes & Yes & Yes & Yes & Yes & Yes \\
\hline Fixed period effects & Yes & Yes & Yes & Yes & Yes & Yes \\
\hline Observations & 902 & 780 & 900 & 780 & 812 & 747 \\
\hline Number of $n$ & 23 & 22 & 23 & 22 & 23 & 22 \\
\hline R-squared (overall) & 0.1662 & 0.1012 & 0.0847 & 0.0612 & 0.0935 & 0.0890 \\
\hline
\end{tabular}

Notes: robust standard errors in brackets; * significant at $10 \%$; ** significant at $5 \%$; ** significant at $1 \%$ 
Table 3: Regression Results.

Bilateral Loans and Bilateral Grants (disbursement/commitment).

Dependent variable: $\Delta$ log Foreign Aid payment of category j (as a share of GDP).

OLS with standard errors robust to heteroskedasticity (Huber/White/sandwich standard errors).

\begin{tabular}{lcccc}
\hline & $(1)$ & $(2)$ & $(3)$ & $(4)$ \\
& $\begin{array}{c}\text { Loans } \\
\text { disbursed }\end{array}$ & $\begin{array}{c}\text { Loans } \\
\text { committed }\end{array}$ & $\begin{array}{c}\text { Grants } \\
\text { disbursed }\end{array}$ & $\begin{array}{c}\text { Grants } \\
\text { committed }\end{array}$ \\
\hline Ideology (leftwing) & 0.0125 & 0.0461 & $0.0197^{* *}$ & $0.0199 * *$ \\
& $(0.0337)$ & $(0.0440)$ & $(0.0076)$ & $(0.0087)$ \\
$\Delta$ log GDP per capita (real) & -0.7759 & -0.6793 & $0.7834^{* *}$ & $1.0018^{*}$ \\
& $(1.6022)$ & $(3.0839)$ & $(0.2953)$ & $(0.5483)$ \\
$\Delta \log$ Size of Government & -0.7558 & -1.4538 & $0.6794 * *$ & $0.8960 * *$ \\
& $(1.0912)$ & $(1.3109)$ & $(0.1458)$ & $(0.3246)$ \\
$\Delta \log$ Trade & -0.6795 & -1.2811 & -0.2927 & -0.0464 \\
Fixed country effects & $(1.4202)$ & $(1.3441)$ & $(0.3333)$ & $(0.5446)$ \\
Fixed period effects & Yes & Yes & Yes & Yes \\
\hline Observations & Yes & Yes & Yes & Yes \\
Number of $n$ & 675 & 567 & 900 & 773 \\
R-squared (overall) & 19 & 19 & 23 & 22 \\
\hline Notes: robust standard errors in brackets; * significant at $10 \% ; *$ significant at 5\%; *** significant at 1\%
\end{tabular}


Table 4: Regression Results.

Bilateral aid - Different recipient income groups. Commitments. Loans/Grants.

Dependent variable: $\Delta \log$ Foreign Aid payment of category j (as a share of GDP).

OLS with standard errors robust to heteroskedasticity (Huber/White/sandwich standard errors).

\begin{tabular}{|c|c|c|c|c|c|c|c|c|c|c|}
\hline & (1) & $(2)$ & (3) & (4) & (5) & (6) & (7) & (8) & (9) & (10) \\
\hline & $\begin{array}{l}\text { Least income } \\
\text { countries }\end{array}$ & $\begin{array}{l}\text { Other lower } \\
\text { income } \\
\text { countries }\end{array}$ & $\begin{array}{l}\text { Lower middle } \\
\text { income } \\
\text { countries }\end{array}$ & $\begin{array}{l}\text { Upper middle } \\
\text { income } \\
\text { countries }\end{array}$ & $\begin{array}{c}\text { More } \\
\text { advanced } \\
\text { developing } \\
\text { countries and } \\
\text { territories } \\
\text { Loans }\end{array}$ & $\begin{array}{l}\text { Least income } \\
\text { countries }\end{array}$ & $\begin{array}{l}\text { Other lower } \\
\text { income } \\
\text { countries }\end{array}$ & $\begin{array}{l}\text { Lower middle } \\
\text { income } \\
\text { countries }\end{array}$ & $\begin{array}{l}\text { Upper middle } \\
\text { income } \\
\text { countries }\end{array}$ & $\begin{array}{c}\text { More } \\
\text { advanced } \\
\text { developing } \\
\text { countries and } \\
\text { territories } \\
\text { Grants }\end{array}$ \\
\hline \multirow[t]{2}{*}{ Ideology (leftwing) } & -0.0940 & 0.0660 & 0.0668 & -0.0265 & -0.0255 & $0.0422 * *$ & 0.0067 & $0.0415^{* * *}$ & 0.0241 & -0.0483 \\
\hline & $(0.0611)$ & $(0.0524)$ & $(0.0422)$ & $(0.0497)$ & $(0.1138)$ & $(0.0168)$ & $(0.0271)$ & $(0.0137)$ & $(0.0246)$ & $(0.0432)$ \\
\hline \multirow[t]{2}{*}{$\Delta$ log GDP per capita (real) } & 0.7325 & 3.7518 & 3.1484 & -0.0534 & $-13.0468 * *$ & 1.0148 & 0.5305 & -2.5049 & 2.6040 & 3.3870 \\
\hline & $(3.7493)$ & $(3.9960)$ & $(4.1297)$ & $(4.5574)$ & $(4.9082)$ & $(0.9853)$ & $(1.1851)$ & $(1.5629)$ & $(1.9755)$ & $(3.1627)$ \\
\hline \multirow[t]{2}{*}{$\Delta \log$ Size of Government } & 1.5059 & -0.2221 & 2.2016 & 2.1695 & -4.6717 & $1.6265^{* *}$ & $1.8391 * *$ & -0.1563 & 1.4159 & 1.8896 \\
\hline & $(2.4805)$ & $(1.8338)$ & (1.8579) & $(2.5613)$ & $(4.1020)$ & $(0.6350)$ & $(0.8508)$ & $(0.8653)$ & $(0.8425)$ & $(1.8415)$ \\
\hline \multirow[t]{2}{*}{$\Delta \log$ Trade } & -0.4115 & -0.8439 & -2.3005 & 1.9715 & 2.7489 & -1.3320 & 0.3817 & -0.5624 & -1.4752 & -0.1323 \\
\hline & $(3.0211)$ & $(1.5013)$ & $(2.4887)$ & $(2.3489)$ & (3.9654) & $(0.7902)$ & $(0.8732)$ & $(1.2350)$ & $(1.0152)$ & (2.0918) \\
\hline Fixed country effects & Yes & Yes & Yes & Yes & Yes & Yes & Yes & Yes & Yes & Yes \\
\hline Fixed period effects & Yes & Yes & Yes & Yes & Yes & Yes & Yes & Yes & Yes & Yes \\
\hline Observations & 403 & 351 & 511 & 361 & 152 & 753 & 740 & 757 & 735 & 450 \\
\hline Number of $n$ & 16 & 16 & 19 & 16 & 9 & 22 & 22 & 22 & 22 & 21 \\
\hline R-squared (overall) & 0.1212 & 0.1224 & 0.0751 & 0.1239 & 0.2375 & 0.0883 & 0.1083 & 0.0989 & 0.1099 & 0.1362 \\
\hline
\end{tabular}

Notes: robust standard errors in brackets; * significant at $10 \%$;* significant at $5 \%$; ${ }^{* *}$ significant at $1 \%$ 
Table 5: Regression Results. Coefficient estimates of the government ideology variable (leftwing) for standard and expansive democracy variable and time-variant and static grouping of democracies/autocracies.

Dependent variable: $\Delta$ log Foreign Aid payment of category $\mathrm{j}$ (as a share of GDP).

OLS with standard errors robust to heteroskedasticity (Huber/White/sandwich standard errors).

\begin{tabular}{|c|c|c|c|c|c|c|c|c|c|c|c|c|c|}
\hline & & $\begin{array}{c}\text { (1) } \\
\text { grants } \\
\text { committed } \\
\text { democratic }\end{array}$ & $\begin{array}{c}\text { (2) } \\
\text { grants } \\
\text { committed } \\
\text { autocratic }\end{array}$ & $\begin{array}{c}(3) \\
\text { total ODA } \\
\text { committed } \\
\text { democratic }\end{array}$ & $\begin{array}{c}(4) \\
\text { total ODA } \\
\text { committed } \\
\text { autocratic }\end{array}$ & $\begin{array}{c}\text { (5) } \\
\text { Loans } \\
\text { committed } \\
\text { democratic }\end{array}$ & $\begin{array}{l}\text { (6) } \\
\text { gross loans } \\
\text { committed } \\
\text { autocratic }\end{array}$ & $\begin{array}{c}\text { (7) } \\
\text { grants } \\
\text { disbursed } \\
\text { democratic }\end{array}$ & $\begin{array}{c}\text { (8) } \\
\text { grants } \\
\text { disbursed } \\
\text { autocratic }\end{array}$ & $\begin{array}{c}\text { (9) } \\
\text { total ODA } \\
\text { disbursed } \\
\text { democratic }\end{array}$ & $\begin{array}{c}(10) \\
\text { total ODA } \\
\text { disbursed } \\
\text { autocratic }\end{array}$ & $\begin{array}{c}\text { (11) } \\
\text { loans } \\
\text { disbursed } \\
\text { democratic }\end{array}$ & $\begin{array}{c}(12) \\
\text { loans } \\
\text { disbursed } \\
\text { autocratic }\end{array}$ \\
\hline \multirow{4}{*}{$\begin{array}{l}\text { Standard Democracy } \\
\text { Time-variant }\end{array}$} & & 0.0271 & $0.0353^{* * *}$ & 0.0220 & 0.0086 & $0.0857 * *$ & -0.0081 & 0.0068 & $0.0237^{*}$ & 0.0198 & 0.0123 & $0.0622 *$ & 0.0099 \\
\hline & & $(0.0246)$ & $(0.0123)$ & $(0.0217)$ & $(0.0176)$ & $(0.0405)$ & (0.0594) & $(0.0175)$ & $(0.0121)$ & (0.0159) & $(0.0123)$ & (0.0308) & (0.0338) \\
\hline & Obs. & 711 & 736 & 744 & 753 & 450 & 503 & 835 & 855 & 851 & 855 & 570 & 612 \\
\hline & \#n & 22 & 22 & 22 & 22 & 18 & 17 & 23 & 23 & 23 & 23 & 19 & 17 \\
\hline \multirow{4}{*}{$\begin{array}{l}\text { Expansive Democracy } \\
\text { Time-variant }\end{array}$} & & $0.0336^{*}$ & $0.0415^{* *}$ & 0.0186 & 0.0315 & $0.0852^{*}$ & 0.0353 & 0.0091 & $0.0353 * *$ & 0.0102 & $0.0303^{*}$ & $0.0581^{*}$ & 0.0460 \\
\hline & & (0.0180) & (0.0154) & (0.0204) & $(0.0223)$ & (0.0441) & (0.0619) & $(0.0182)$ & $(0.0153)$ & $(0.0148)$ & $(0.0162)$ & (0.0331) & (0.0399) \\
\hline & Obs. & 725 & 732 & 749 & 749 & 490 & 472 & 842 & 855 & 851 & 855 & 593 & 592 \\
\hline & $\# \mathrm{n}$ & 22 & 22 & 22 & 22 & 18 & 17 & 23 & 23 & 23 & 23 & 19 & 17 \\
\hline \multirow{4}{*}{$\begin{array}{l}\text { Standard Democracy } \\
\text { Static }\end{array}$} & & 0.0187 & 0.0236 & 0.0202 & 0.0073 & 0.0525 & -0.0130 & -0.0030 & 0.0170 & 0.0213 & 0.0032 & 0.0345 & 0.0108 \\
\hline & & $(0.0250)$ & (0.0179) & $(0.0258)$ & $(0.0226)$ & $(0.0572)$ & $(0.0603)$ & $(0.0259)$ & $(0.0114)$ & (0.0279) & $(0.0128)$ & $(0.0429)$ & (0.0359) \\
\hline & Obs. & 693 & 733 & 727 & 751 & 311 & 472 & 808 & 847 & 820 & 850 & 441 & 573 \\
\hline & $\# n$ & 22 & 22 & 22 & 22 & 16 & 17 & 23 & 23 & 23 & 23 & 16 & 17 \\
\hline \multirow{4}{*}{$\begin{array}{l}\text { Expansive Democracy } \\
\text { Static }\end{array}$} & & 0.0166 & $0.0957^{* * *}$ & 0.0146 & $0.0813^{*}$ & -0.0359 & -0.0454 & 0.0056 & $0.0617^{* * *}$ & 0.0212 & $0.0611^{* *}$ & 0.0219 & -0.0428 \\
\hline & & (0.0197) & $(0.0324)$ & (0.0248) & (0.0469) & $(0.0815)$ & $(0.0761)$ & $(0.0204)$ & $(0.0209)$ & $(0.0245)$ & $(0.0253)$ & $(0.0380)$ & $(0.0835)$ \\
\hline & Obs. & 701 & 701 & 732 & 718 & 352 & 315 & 824 & 818 & 838 & 821 & 477 & 454 \\
\hline & $\# n$ & 22 & 22 & 22 & 22 & 16 & 17 & 23 & 23 & 23 & 23 & 16 & 17 \\
\hline \multirow{4}{*}{$\begin{array}{l}\text { Standard Democracy } \\
\text { Static (median cutoff) }\end{array}$} & & $0.0218^{*}$ & $0.0323^{*}$ & 0.0182 & 0.0029 & $0.1013^{* *}$ & -0.0158 & 0.0162 & $0.0207^{*}$ & 0.0094 & 0.0040 & $0.0661^{*}$ & 0.0505 \\
\hline & & (0.0109) & $(0.0172)$ & (0.0176) & (0.0209) & $(0.0449)$ & (0.0657) & (0.0113) & (0.0119) & $(0.0156)$ & (0.0121) & $(0.0331)$ & (0.0369) \\
\hline & Obs. & 730 & 733 & 753 & 748 & 485 & 488 & 840 & 852 & 853 & 852 & 601 & 599 \\
\hline & \#n & 22 & 22 & 22 & 22 & 17 & 18 & 23 & 23 & 23 & 23 & 17 & 19 \\
\hline \multirow{4}{*}{$\begin{array}{l}\text { Expansive Democracy } \\
\text { Static (median cutoff) }\end{array}$} & & $0.0295^{* *}$ & $0.0376^{* *}$ & 0.0099 & 0.0246 & 0.0447 & 0.0470 & 0.0162 & 0.0211 & 0.0090 & 0.0145 & 0.0456 & 0.0483 \\
\hline & & (0.0130) & $(0.0148)$ & (0.0164) & (0.0205) & $(0.0530)$ & (0.0684) & (0.0099) & (0.0128) & $(0.0111)$ & (0.0149) & (0.0298) & (0.0375) \\
\hline & Obs. & 730 & 733 & 753 & 748 & 485 & 488 & 840 & 852 & 853 & 852 & 601 & 599 \\
\hline & $\# n$ & 22 & 22 & 22 & 22 & 17 & 18 & 23 & 23 & 23 & 23 & 17 & 19 \\
\hline
\end{tabular}

Notes: robust standard errors in brackets; ${ }^{*}$ significant at $10 \%$; ${ }^{*}$ significant at $5 \% ;{ }^{* * *}$ significant at $1 \%$ 
Table 6: Regression Results.

Bilateral aid - Tied and untied aid. Commitment.

Dependent variable: $\Delta$ log Foreign Aid payment of category j (as a share of GDP).

OLS with standard errors robust to heteroskedasticity (Huber/White/sandwich standard errors).

\begin{tabular}{|c|c|c|c|c|c|c|c|c|}
\hline & $\begin{array}{c}\text { (1) } \\
\text { Untied aid } \\
\text { Grants }\end{array}$ & $\begin{array}{c}\text { (2) } \\
\text { Untied aid } \\
\text { Loans }\end{array}$ & $\begin{array}{c}\text { (3) } \\
\text { Tied aid } \\
\text { Grants }\end{array}$ & $\begin{array}{c}\text { (4) } \\
\text { Tied aid } \\
\text { Loans }\end{array}$ & $\begin{array}{l}\text { (5) } \\
\text { Untied and } \\
\text { partially tied } \\
\text { aid }\end{array}$ & $\begin{array}{c}\text { (6) } \\
\text { Untied and } \\
\text { partially tied } \\
\text { aid }\end{array}$ & $\begin{array}{c}\text { (7) } \\
\text { Tied and } \\
\text { partially tied } \\
\text { aid }\end{array}$ & $\begin{array}{c}\text { (8) } \\
\text { Tied and } \\
\text { partially tied } \\
\text { aid }\end{array}$ \\
\hline & & & & & Grants & Loans & Grants & Loans \\
\hline Ideology (leftwing) & $\begin{array}{c}0.0632 * * \\
(0.0248)\end{array}$ & $\begin{array}{l}-0.0140 \\
(0.0498)\end{array}$ & $\begin{array}{c}0.1203 * * \\
(0.0513)\end{array}$ & $\begin{array}{c}-0.1202 \\
(0.0906)\end{array}$ & $\begin{array}{c}0.0661 * * \\
(0.0257)\end{array}$ & $\begin{array}{l}-0.0138 \\
(0.0554)\end{array}$ & $\begin{array}{c}0.1183^{* *} \\
(0.0498)\end{array}$ & $\begin{array}{l}-0.0522 \\
(0.0426)\end{array}$ \\
\hline$\Delta$ log GDP per capita (real) & $\begin{array}{c}-1.3377 \\
(1.4474)\end{array}$ & $\begin{array}{c}-1.7996 \\
(5.7939)\end{array}$ & $\begin{array}{c}2.2215 \\
(2.5587)\end{array}$ & $\begin{array}{l}10.1124 \\
(6.7679)\end{array}$ & $\begin{array}{l}-1.3119 \\
(1.3459)\end{array}$ & $\begin{array}{l}-3.7940 \\
(6.8775)\end{array}$ & $\begin{array}{c}2.9084 \\
(2.6014)\end{array}$ & $\begin{array}{c}13.5854 * \\
(6.4446)\end{array}$ \\
\hline$\Delta \log$ Size of Government & $\begin{array}{c}-0.2714 \\
(1.1716)\end{array}$ & $\begin{array}{c}2.9739 \\
(2.7449)\end{array}$ & $\begin{array}{l}-2.1895 \\
(2.4561)\end{array}$ & $\begin{array}{c}2.6930 \\
(2.7261)\end{array}$ & $\begin{array}{c}0.1048 \\
(1.0420)\end{array}$ & $\begin{array}{c}1.3078 \\
(2.9806)\end{array}$ & $\begin{array}{l}-0.2473 \\
(2.3187)\end{array}$ & $\begin{array}{c}4.1599 \\
(3.2175)\end{array}$ \\
\hline$\Delta \log$ Trade & $\begin{array}{c}0.0283 \\
(1.2443)\end{array}$ & $\begin{array}{c}2.9556 \\
(2.4702)\end{array}$ & $\begin{array}{l}-1.0480 \\
(1.8420)\end{array}$ & $\begin{array}{c}1.4671 \\
(2.2200)\end{array}$ & $\begin{array}{c}0.0561 \\
(1.2318)\end{array}$ & $\begin{array}{c}3.2281 \\
(2.5980)\end{array}$ & $\begin{array}{c}-0.4763 \\
(1.6211)\end{array}$ & $\begin{array}{l}-0.4733 \\
(1.9118)\end{array}$ \\
\hline Fixed country effects & Yes & Yes & Yes & Yes & Yes & Yes & Yes & Yes \\
\hline Fixed period effects & Yes & Yes & Yes & Yes & Yes & Yes & Yes & Yes \\
\hline Observations & 491 & 263 & 441 & 232 & 491 & 269 & 453 & 245 \\
\hline Number of $n$ & 22 & 19 & 22 & 17 & 22 & 19 & 22 & 17 \\
\hline R-squared (overall) & 0.1033 & 0.1072 & 0.1058 & 0.0940 & 0.1011 & 0.0825 & 0.0849 & 0.1336 \\
\hline
\end{tabular}

Notes: robust standard errors in brackets; ${ }^{*}$ significant at $10 \% ;{ }^{* *}$ significant at $5 \%$; ${ }^{* * *}$ significant at $1 \%$ 
Table 7: Regression Results.

Bilateral aid by sector. Commitments.

Dependent variable: $\Delta \log$ Foreign Aid payment of category $\mathrm{j}$ (as a share of GDP).

OLS with standard errors robust to heteroskedasticity (Huber/White/sandwich standard errors).

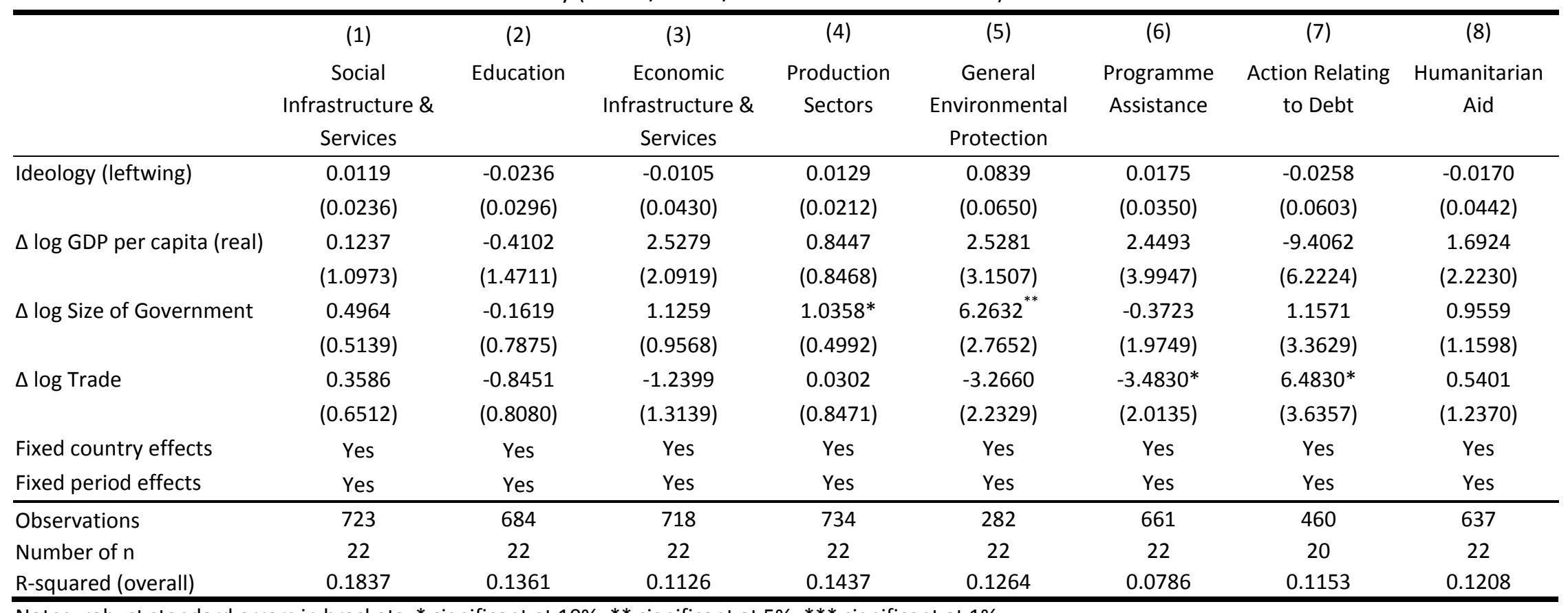

Notes: robust standard errors in brackets; * significant at $10 \% ; * *$ significant at $5 \% ; * *$ significant at $1 \%$ 